Т. о. Шундель

\title{
ДО ПИТАННЯ ПРО ДИФЕРЕНЦАЦІЮ ОПОЗИЦІЇ СУРЯДНІСТЬ / ПІДРЯДНІСТЬ У НАУКОВІЙ ЛІТЕРАТУРІ
}

\begin{abstract}
Шундель Т. О. До питання про диференціацію опозиції сурядність / підрядність у науковій літературі.

У статті досліджено питання диференціації понять сурядність / підрядність, проаналізовано складні речення 3 трансформованою семантикою. Доведено ілюстративно, що опозиційні стосунки синтаксичних одиниць свідчать про синкретичнизм плану змісту.
\end{abstract}

Ключові слова: складнопідрядне речення, складносурядне речення, синкретизм, опозиційні стосунки.

Шундель Т. О. К вопросу о дифференциации оппозиции сочинение / подчинение в научной литературе.

В статье исследуется вопрос дифференциации понятий сочинение / подчинение, анализируются сложные предложения с трансформированной семантикой. Иллюстративно доказывается, что оппозиционные отношения синтаксических единиц свидетельствуют о синкретизме плана содержания.

Ключевые слова: сложноподчиненное предложение, сложносочиненное предложение, синкретизм, оппозиционные отношения.

Shundel T. A. To the question of the differentiation of the opposition coordination / subordination in the research literature.

The article deals with question of the differentiation of the notions coordination / subordination, composite sentences with transformed semantics are analysed. The author reasons that opposition relations of syntactic unities indicate sencretism of the meaning. opposition.

Key words: complex sentence, compound sentence, syncretism, relations of

Звернення учених до форми складного речення збагатило мову численними знаннями про систему зв'язку між компонентами складного речення, про принципи та закономірності місця розташування й послідовності елементів складного речення. Проте, фактично не додалося знань про змістовну базу значущих понять сурядності / підрядності, при тлумаченні яких ми досі продовжуємо використовувати нечіткі уявлення. Аналіз літератури 3 окресленої 
проблеми дає підстави вважати, що при вивченні конкретних видів складного речення не звертається достатньої уваги на смислове наповнення та змістовний бік координації мови, що i зумовлює актуальність наукового пошуку. Мета статі - дослідити різницю між складнопідрядним та складносурядним реченням та 3'ясувати, у який спосіб здійснюється зв'язок в смисловому плані між частинами речення. Часткові завдання, розв'язання яких передбачає мета дослідження, спрямовано передусім на 1) зіставлення опозиційних відношень мовних одиниць на рівні речення, 2) визначення характеру відмінностей зв'язку у складнопідрядному та у складносурядному реченнях, 3) виявлення специфічності значеннєвого навантаження маркувальних компонентів.

Питання про природу підрядної частини складнопідрядного речення (далі СПР) вирішувалося мовознавчою наукою суперечливо й неоднозначно. Огляд лінгвістичної літератури свідчить, що досліджувана структура на сьогодні не має всебічного детального аналізу. Вагомий внесок у розробку цього питання зробили М. Петерсон, О. Гвоздєв, В. Жельвіс, Б. Ільїш, Ю. Гепнер, Л. Іофик, С. Ширяєв, І. Верховська, Я. Біренбаум та ін.

Тривалий час у мові не існувало теорії вивчення речення, але панувала гіпотеза, що безпосередня послідовність одного головного речення за іншим визначалася як parataxis (паратаксис), тобто сурядність, на противагу hypotaxis (гіпотаксис), що означає підрядність [4]. Як зауважує Б. Дельбрюк, ідея щодо виникнення гіпотаксису від паратаксису стає провідною [17, с. 413]. Аналізуючи паратактичні та гіпотактичні засоби зв'язку, Л. Теньєр стверджував: «Як правило, мови спочатку виражають складні думки у формі паратаксису і лише в ході свого розвитку вони отримують здатність помічати і виражати гіпотетичні зв'язки ...» [1, с. 383]. Існують усі підстави врахувати поправку дослідника Бернарда, який наголошував, що просте речення так відноситься до періоду (до складного речення), як слово - до простого речення [16].

М. Петерсон пропонував не акцентувати увагу на існуючих термінах паратаксис / гіпотаксис, головне / підрядне речення, вважаючи, що в мові відсутні реальні причини пояснення фактів відмінності головного речення від підрядного або сурядності від підрядності. Головний показник цього він вбачає у відсутності діючих критеріїв їх відмінності [1, с. 28-29]. 
Далі дослідник критикує визначення підрядності, яке наводить Кюнер [18, с. 865]. Зміст підрядності, за Кюнером, полягає в тому, що за його допомоги два або декілька речень об'єднуються в одне, 3 яких головне доповнюється та пояснюється підрядним, і при цьому усі речення являють собою органічну єдність форм і виражають одну думку. Наприклад, візьмемо два складних речення: She was not a beauty although her features were rather good [13, c. 89]; Michael and Julia were a good pair but the relations between them were rather cold [13, c. 57]. Як у першому, так i в другому разі обидва речення поєднуються за допомогою сполучників (although, but), представляючи собою органічну єдність форм й виражаючи одну думку. Отже, М. Петерсон робить висновок, що взагалі немає різниці між сурядністю та підрядністю [1, с. 32].

Поглиблений аналіз складних речень дає підстави вважати, що помітна відмінність між СПР та ССР слід убачати в об'ємі передачі інформації. У СПР спостерігається включення інформації підрядної частини до головної (...we didn't see that it was anyone else's business) i навпаки (Joseph wasn't listening as he excitedly gathered leaflets that were thrown through the open window). В умовах сурядності ми спостерігаємо ранжування інформаційного потоку, яке інтерпретує повідомлені події як однорангові (але не завжди рівноправні) [12, с. 57-58]. Говорячи про різні засоби передачі інформації, треба враховувати, що для підрядності та сурядності характерний певний набір специфічних засобів. У кожному випадку осмислення характеру інформації в структурну основу речень вводяться своєрідні єднальні елементи, використання яких іноді призводять до зсуву смислових векторів того самого явища.

При аналізі формальної та структурної сторін СПР лінгвісти пропонували враховувати семантику мовної одиниці як одну із диференційних ознак СПР. Так, Г. Колшанський пропонує звертати увагу на змістовну сторону та семантичну структуру, враховуючи різні форми думки, які передаються в СПР. 3 одного боку, СПР, на відміну від ССР, являє собою конструкцію, частини якої об'єднані єдиною предикацією [10, с. 193]. 3 іншого боку, СПР - це одиниця, яка розглядається як суцільне судження 3 логічним зв'язком субординації між його частинами, тоді як ССР - одиниця, частини якої $\epsilon$ самостійними судженнями із стосунками координації. Так, однією із головних ознак розмежування СПР та ССР вважається висвітлення питання про типи синтаксичного зв'язку (сурядний або підрядний), 
який розрізняється у наступних аспектах: на рівні поєднання синтаксичних слів та на власне-реченнєвому рівні [9, с. 22].

Розгляд синтаксичного зв'язку здійснюється на підставі характеристики певних смислових та формальних категорій, які знаходять своє вираження на рівні речення. У зв'язку з цим В. Жельвіс [7, с. 254; 8, с. 344] відзначав, що сурядній зв' язок сполучає абсолютно рівноправні синтаксичні компоненти в реченні на відміну від підрядного зв'язку, елементи якого вказують на залежний характер. Отже, компоненти сурядного зв'язку характеризуються єдністю смислової, граматичної й ритмомелодичної ознаки. Головним показником одиниць СПР насамперед є те, що тільки головна частина має незалежність цієї ознаки, а між головною та підрядною частинами здійснюється тісний зв'язок в смисловому плані. Приклади різновидів відношень на рівні речень становлять сполучники сурядності й підрядності. Це дає підстави вважати, що саме сполучник використовується для поширення розгорнутості висловлювання та $є$ носієм модифікованої семантики реченнєвих структур, які диференціюють специфіку синтаксичних форм. Певний внесок у розв'язання цього питання зробила С. Гулига, яка, досліджуючи структурні та смислові ознаки СПР, відмічала можливість синонімічних стосунків між паратаксисом i гіпотаксисом. Таку синонімію вона назвала «семантико-синтаксичною», підкреслюючи той факт, що «певні семантико-синтаксичні стосунки між елементарними реченнями можуть бути виражені як за допомогою підрядності, так і за допомогою сурядності» [6, с. 194].

3 питання встановлення відмінностей в опозиції сурядні / підрядні сполучники, що перетинається 3 опозицією сурядність / підрядність, широко відома дискусія між лінгвістами М. Петерсеном [1, с. 28-35] та О. Пєшковським [14, с. 132]. На думку М. Петерсона, у реченнях, які поєднані сурядним засобом спостерігаються тотожні ознаки 3 підрядним: при сурядності чи підрядності другий елемент складного речення самостійного значення не має. Якщо ми відкинемо сполучники (елемент, який за інших умов з'явитися не може), то другий компонент складного речення $є$ таким же самостійним реченням, як і перший. При цьому в обох випадках єдність складного речення створюється за допомогою інтонації.

Так, полемізуючи з М. Петерсеном, який заперечував існування головних ознак відмінності СПР від ССР, О. Пєшковський вказував на очевидність цих ознак, пропонуючи більш зважене вирішення 
проблеми - урахування ознаки зворотності - незворотності стосунків в аналізованих структурах. На його думку, сурядні сполучники - такі одиниці, які при збереженні своїх позицій, здатні змінювати розташування предикативних елементів при збереженні основного сенсу. Звідси випливав висновок: сурядний сполучник не є структурним елементом жодної предикативної конструкції, а просто сполучує їх. Наприклад: His mouth twitched and he appeared embarrassed [19, с. 1] He appeared embarrassed and his mouth twitched; It sounds very exciting and I bet he's a nice man [19, c. 18] - I bet he's a nice man and it sounds very exciting.

Підрядний зв'язок розглядався дослідником як засіб стосунків, який при зміні позицій предикативних елементів в умовах збереження місця сполучника (сполучникового слова), призводить до зміни сенсу усього складного речення, його глибинної структури. Так, у наступних реченнях, змінюючи фіксовані позиції предикативних частин, повністю руйнується значеннєве навантаження СПР, пор.: a) Unfortunately you will have to leave the house if you don't wish to work with him [19, c. 2] - You don't wish to work with him if unfortunately you will have to leave the house; б) She remembered thinking to herself that he sounded a bit of a weed [19, c. 7] - He sounded a bit of a weed that she remembered thinking to herself.

У такому трактуванні вбачаються усі підстави стверджувати, що підрядний сполучник являє собою структурний елемент однієї 3 предикативних конструкцій і маркувальний компонент підрядної частини.

Проте, іноді при зміні місця предикативних частин може статися деформація закладеної змістовної інтерпретації [14, с. 194]. Наприклад: a) Katherine didn't want to offend Dolly but she hadn't envisaged living near the docks [19, c. 19] - She hadn't envisaged living near the docks but Katherine didn't want to offend Dolly; б) She beamed and her beautiful blue eyes twinkled [19, с. 66] - Her beautiful blue eyes twinkled and she beamed.

Існують усі підстави врахувати поправку В. Бєлошапкової [3, с. 94-95], яка, говорячи про засоби зв'язку в реченнях, наголошувала, що підрядний сполучник багато в чому схожий з сурядним, оскільки входить до складу одного із структурних, предикативних елементів.

На нашу думку, можна констатувати, що теоретично не існує ідеальних базисів для розмежування сурядних / підрядних сполучників, а, отже, СПР та ССР. У такій опозиції в розрізненні сполучників мовознавець Є.Ширяєв [15, с. 51] пропонує враховувати змістовну сторону: підрядні сполучники з'єднують нерівноправні синтаксичні 
конструкції, а сурядні сполучники поєднують предикативні частини, які знаходяться в схожих стосунках $з$ іншими предикативними елементами. Не зважаючи на специфічність граматичного значення сполучника, підрядний сполучник використовується для вираження підпорядкування одного компонента іншому на відміну від граматичної функції сурядного сполучника, головна особливість якого міститься у вираженні однакового співвідношення елементів.

Бінарне протиставлення синтаксичного зв'язку (сурядний / підрядний) вказує на можливість нейтралізації цієї опозиції в деяких синтагматичних умовах. Явище синтаксичної нейтралізації, яке згодом призводить до виникнення синкретичних форм, на думку Дж. Лайонза, - широко поширений факт в мові [14, с. 270]. Нейтралізація опозиційних стосунків спостерігається в складних реченнях, які мають, з одного боку, єднальні елементи - підрядні сполучники, а, 3 іншого боку, - їм притаманні особливості ССР (константна позиція предикативних частин, своєрідний співвідносний зв’язок структурних компонентів). Однак, незважаючи на велику кількість накопиченого фактичного матеріалу щодо питання опозиційних відношень СПР / ССР, мовознавцями висловлюється думка, що між цими типами речень не завжди можна встановити чітку межу: той самий сполучник може вказувати на різні стосунки в реченні, сурядні або підрядні. Наприклад, сполучник while виконуває в наступних реченнях не тільки функцію граматичного показника сурядності: While she was talking to Katherine her sharp beady eyes were darting round the room [19, c. 41] - She was talking to Katherine and her sharp beady eyes were darting round the room, але й функцію підрядності (часові відношення): While you are old enough to understand I shall tell you the full story [19, c. 33].

У наведених прикладах сполучник while не вживається у своєму головному темпоральному значенні, а використовується для передачі зіставних, єднальних стосунків, тобто, за формою ці речення можуть бути визначені як СПР, а в семантичному плані - ССР, оскільки самостійність синтаксичних конструкцій дозволяє трансформувати підрядний сполучник while в сурядний сполучник and, який докорінно не міняе смислового змісту речень.

В обох випадках спостерігається наявність кількох предикативних центрів, але різних засобів зв'язку, які чинять диференціальний вплив на тимчасову настанову речення в цілому. Так, сурядний сполучник and (while) розкриває сему часу в 
найзагальнішому вигляді, а підрядний сполучник while має конкретне лексичне значення, яке передає темпоральне відношення деталізованого повідомлення в підрядній частині.

Аналогічні приклади спостерігаємо у складних речення із підрядним сполучником when, який, як і сполучник and або but, може вживатися для передачі єднальних або протиставних сурядних відношень. Так, схожість між СПР та ССР 3 тимчасовим значенням передається за допомогою єдності смислових та семантичних стосунків, спрямованих до загальної глибинної структури. Порівняйте такі приклади: When she'd confronted Gerald about it he had told her to see Mr. Cannon [19, c. 2] - She'd confronted Gerald about it and he had told her to see Mr. Cannon; I was dusting the front door when I saw you $[19$, c. 26] - I was dusting the front door and I saw you.

Синонімія конструкцій з підрядним та сурядним зв'язком, який передає ідентичні темпоральні стосунки, спостерігається в умовах трансформації мовних елементів речень. Наприклад: Gerald thanked the vicar and the assembled guests began to slowly move away [19, c. 8] After Gerald thanked the vicar the assembled guests began to slowly move away; The business had grown and they moved into larger premises near to Green Park and opened the restaurant [19, c. 26] - After the business had grown they moved into larger premises near to Green Park and opened the restaurant.

Лінгвісти неодноразово відзначали, що в мові простежуються периферійні, синкретичні зони, які зближують СПР із ССР, тим самим утрудняючи віднесення речень до того чи того типу. Так, ССР з причинонаслідковими стосунками (for, so, so that) близькі за своєю природою до СПР причини та наслідку (as, so, so that, because та ін.), а також ССР 3 протиставно-допустовими стосунками (but, and) близькі до СПР 3 підрядною частиною, що виражає допустові стосунки (though, although та ін.). Наприклад: Mr. Cannon, a tall middle-aged man, looked the perfect solicitor, but he appeared uncomfortable as with his finger he eased the stiff white shirt collar away from his flabby neck [19, c. 1]; Panic again surged in Katherine, but she knew she had to act calmly to hide her fear from her son [19, c. 4]; The windows were tightly shut and heavily draped though it was a warm bright spring morning [19, c. 1]; The family would never accept her although she had two sisters she could never go back home [19, c. 11].

У цих ілюстраціях у ССР, частини яких з'єднуються сполучником but, та в СПР, предикативні частини яких пов'язані сполучниками though / although, також демонструються зразки нейтралізації опозиції 
сурядність / підрядність, оскільки вони з легкістю можуть замінювати один одного, не перекручуючи сенс цілого речення: Mr. Cannon, a tall middle-aged man, looked the perfect solicitor, but he appeared uncomfortable as with his finger he eased the stiff white shirt collar away from his flabby neckMr. Cannon, a tall middle-aged man, looked the perfect solicitor though he appeared uncomfortable as with his finger he eased the stiff white shirt collar away from his flabby neck; Panic again surged in Katherine, but she knew she had to act calmly to hide her fear from her son - Panic again surged in Katherine though she knew she had to act calmly to hide her fear from her son; The windows were tightly shut and heavily draped though it was a warm bright spring morning - The windows were tightly shut and heavily draped but it was a warm bright spring morning; The family would never accept her although she had two sisters she could never go back home - The family would never accept her but she had two sisters she could never go back home.

Аналогічна ситуація спостерігається при вживанні сполучників so, for, as, які можуть бути замінені так: Dolly wanted a few small bits as her and Tom's always been in service, so I was lucky enough to get it [19, c. 29] Dolly wanted a few small bits as her and Tom's always been in service that's why I was lucky enough to get it (заміна сурядного сполучника so підрядним сполучником that's why); The weekend of the party got closer so the food and the flowers arrived and preparations began in earnest [19, c. 40] - The weekend of the party got closer and the food and the flowers arrived and preparations began in earnest (заміна підрядного сполучника so сурядним сполучником and); Joseph was happy but said very little to his mother, for there was still a big gulf between them [19, c. 36] - Joseph was happy but said very little to his mother because there was still a big gulf between them (заміна сурядного сполучника for підрядним сполучником because); So you see I would never work or live with you as I haven't the same respect for you as I did for Edwin [19, c. 9] - So you see I would never work or live with you, for I haven't the same respect for you as I did for Edwin (заміна підрядного сполучника as сурядним сполучником for).

Проведений аналіз випадків нейтралізації на рівні складного речення призводить до думки, що нейтралізація - явище синтагматичного порядку, яке простежується в рамках контексту та реалізується в певних опозиційних стосунках синтаксичних одиниць. Явище нейтралізації синтаксичних опозицій - приклад синкретичності плану змісту, що співвідноситься 3 певною зовнішньою формою, оскільки форма не може існувати без змісту, хоча іє умовною. 
Відмінна риса СПР від ССР полягає в тому, що у смисловому плані підрядна частина СПР розкриває та збагачує змістовну сторону головної частини, а у ССР другий компонент речення виявляється за рахунок першого. Отже, про характер відмінності СПР від ССР свідчить особливість місця розташування частин, які вводяться за допомогою різноманітних сполучників. Загальновизнаним і єдиним порядком розташування предикативних одиниць в ССР визнається наступний: частина речення без сполучника - сполучник координації - друга частина речення. Наприклад: Mr. Cannon, a tall middle-aged man, looked the perfect solicitor, but he appeared uncomfortable as with his finger he eased the stiff white shirt collar away from his flabby neck [19, c. 1]; Katherine hadn't been looking forward to moving to Rotherhithe, and this outburst with Joseph had finally made up her mind [19, c. 34].

Проте, не варто брати до уваги тільки чіткі розмежування СПР від ССР, поглибленій аналіз опозиції сурядність / підрядність дає підстави вважати, що подібні стосунки в СПР та ССР можуть передаватися за допомогою особливих специфічних сполучників (тотожних один одному або абсолютно відмінних один від одного), властивих тому або іншому типу речення. Ідентичність виражених семантичних відношень у СПР та у ССР вказує на формально-семантичну змістовну схожість в обох типах речень: як в СПР, так і в ССР відбувається складання семантики предикативних одиниць за умови координації категорійної семантики предикативних частин. Через це змістовна сторона семантикосемантичних відношень подібна в структурних одиницях ССР та СПР [5, с. 33]. За нашими спостереженнями, усе це говорить про омонімію сполучників в англійській мові.

Відзначимо і те, що при об'єднанні у складні конструкції сурядного та підрядного зв'язків іноді утворюються синкретичні одиниці. До них відносимо, наприклад, утворення, у яких сурядність у межах залежного складу здійснюється всупереч структурним або структурно-семантичним обмеженням, які накладаються головною частиною: But most of all he was impressed by a letter-box where he could drop a letter and it came to anybody [13, c. 134]. У цьому прикладі виокремленна частина сурядна 3 початковою ланкою залежного складу не сумісна 3 головною предикативною одиницею ні в суряному, ні в підрядному відношенні, що й підтверджується перестановкою: But most of all he was impressed by a letter-box ... it came to anybody.

Відсутність різких відмінних особливостей між ССР та СПР пояснюється тим, що спосіб вираження стосунків в ССР та СПР 
знаходиться у позиції взаємодії, але не протиставлення. Перешкоди визначення понять сурядність / підрядність утруднюється фактом існування різноманітних форм та мір синтаксичної залежності між компонентами речення.

Усі ці формальні критерії диференціації опозиції сурядність підрядність вказують на неоднорідний характер стосунків зв' язку між частинами складного речення. Отже, ми переконуємося в суперечливому характері зв'язку, який проявляє ознаки тісної взаємодії або, навпаки, наштовхує нас на думку про існування проміжного ряду речень між СПР та ССР. Паралелізм розвитку характеру взаємостосунків між частинами складного речення служить приводом для розгляду класифікації СПР та чіткого розмежування виділення типів останніх.

Схожі явища входять до «царини перехідних утворень, які характеризуються синтезом (сумісництвом) диференційних ознак», які й складають зону синкретизму. Актуальність їх дослідження зумовлена тенденцією до розширення об'єктів опису, що характерна для граматики останніх десятиліть, й перспективністю розгляду синкретичних одиниць для уточнення властивості полярних сфер. «Ггнорувати зону синкретизму - означає скорочувати і об'єднувати об' єкт дослідження» [2, с. 3-14].

Аналіз теоретичного матеріалу та дібрані лінгвофакти дозволяють стверджувати, що при подальшому аналізі СПР перспективним представляється вивчення власне-семантичного та семантико-синтаксичного аспектів цієї одиниці, які допоможуть виявити причини виникнення синкретизму. Вважаємо за доцільне розглянути питання типологічного дослідження периферійних конструкцій СПР та спробувати надати чітку класифікацію СПР 3 урахуванням синкретичних відтінків.

\section{Література}

1. Астахова Л. И. Предложение и его членение: Прагматика, семантика, синтаксис : [монография] / Л. И. Астахова. - Днепропетровск : ДГУ, 1992. - 160 с.

2. Бабайцева В. В. Место переходных явлений в системе языка (на материале частей речи) / В. В. Бабайцва // Переходность и синкретизм в языке и речи. - М. : Прометей, 1991. - C. 3-14.

3. Белошапкова В. А. Сложное предложение в современном русском языке / В. А. Белошапкова. - М. : Просвещение, 1967. - С. 94-95.

4. Валгина Н. С. Синтаксис современного русского языка / Н. С. Валгина. - М. : Высшая школа, 1978. - 439 с. 
5. Гаврилова Г. Ф. Переходные конструкции в синтаксисе сложного предложения и их системные отношения : [учебное пособие по курсу] / Г. Ф. Гаврилова. - Ростов н/Д : РГПИИ, 1985. - C. 33 .

6. Гулыга Е. В. Теория сложноподчиненного предложения в современном немецком предложении / Е. В. Гулыга. - М. : Высшая школа, 1971. - С. 194.

7. Жельвис В. И. Существуют ли в языке сочинительные и подчинительные союзы (на материале английского языка) / В. И. Жельвис // Учёные записки Ленинградского государственного педагогического института. Вопросы английской филологии. - Л., 1962. - Т. 226. - С. 253-273.

8. Жельвис В. И. К вопросу о видах синтаксической святи между частями сложного союзного предложения (на материале английского языка) / В. И. Жельвис // Учёные записки Ленинградского государственного педагогического института. Кафедра английского языка. - Л., 1958. - Т. 181. Вып. 3. - С. 343-366.

9. Загнітко А. П. Закономірності формальної і смислової організації складного речення / А. П. Загнітко // Лінгвістичні студії : зб. наук. праць. - Донецьк : ДонНу, 1996. C. 17-27.

10. Колшанский Г. В. Логика и структура язика / Г. В. Колшанский. - М. : Высшая школа, 1965. - С. 193.

11. Лайонз Дж. Введение в теоретическую лингвистику / Дж. Лайонз. - М. : Высшая школа, 1978. - С. 270.

12. Ломов А. М. Русское сложноподчиненное предложение и проблема его содержательной интерпретации / А. М. Ломов, Р. Гусман Тирадо // Вопросы языкознания. 1999. - № 6. - С. 54-65.

13. Моэм У. Сомерсет. Театр. Роман. На англ. яз. / Комментарий М. В. Дьячкова / У. Сомерсет Моэм. - М. : Издательство «Менеджер», 2005. - 304 с.

14. Пешковский А. М. Существует ли в русском языке сочинение и подчинение предложений : Избранные труды / А. М. Пешковский. - М., 1959. - С. 132-140.

15. Ширяев Е. Н. Дифференциация сочинительных и подчинительных союзов на синтаксической основе / Е. Н. Ширяев // Филологические науки. - 1980. - № 2. - С. 51-62.

16. Bernhardi A. F. Anfangsgründe der Sprachwissenschaft / A. F Bernhardi. - Berlin, 1985. - S. 345 .

17. Delbrück B. Vergleichende: Syntax. III / Delbrück B. - Berlin, 1980. - S. 13.

18. Kühner. Grammatik der. Greich: Syntax II / Kühner. - Berlin, 1987. - S. 867.

19. Williams Dee. Katie's Kitchen / Dee Williams. - Great Britain : Headline Book Publishing, 1999. - 375 p.

Стаття надійшла до редакції 10.09.2012 р. 